\title{
Preparation of Self Microemulsion of Ferulic Acid
}

Jinhui Zuo, Qiang Li, Zeyuan Dong, Hong Meng, Li Li, Yinmao Dong*

China Cosmetic Collaborative Innovation Center, Beijing Technology and Business University, Beijing, China

*Corresponding author: Yinmao Dong, China Cosmetic Collaborative Innovation Center, Beijing Technology and Business University, No. 11/33, Fucheng Road, Haidian District, Beijing, China Tel.: +861068984937

Fax.: +861068984937

Email: ymdong2008@163.com

Received March 27, 2017

Revised May 19, 2017

Accepted May 29, 2017

Published September 30, 2017

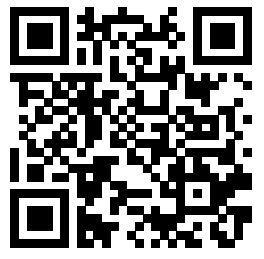

\begin{abstract}
Purpose: The optimum formulation and preparation process of ferulic acid self microemulsion was studied. Methods: The effect of different surfactants on the formation of microemulsion area was studied by pseudo three phase diagram method. To determine the best ratio among surfactants, cosurfactant and oil phase, the uniformity and particle size of microemulsion was evaluated by nanoparticle size analyzer. Finally, the stability of microemulsion was measured by nanoparticle size analyzer and zeta potential analyzer. Results: Combined the results of pseudo three phase diagram with particle size distribution, the best ratio of self microemulsion:polyoxyethylene castor oil (Cremophor EL): polyethylene glycol 40 (PEG 40):Ethanol:isopropyl myristate (IPM) is about 3.15:3.15:1.8:1. The average particle size of microemulsion is about $15.5 \mathrm{~nm}$ which of system contains about $90 \%$ water. The maximum drug loading of ferulic acid was $5.2 \%$, and this self microemulsion formulation has good stability. Conclusion: The formula greatly improves the solubility of insoluble materials like ferulic acid in water and it has guiding significance for the application of the microemulsion in practical production.
\end{abstract}

Keywords: Whitening, Ferulic acid, Formulation process, Microemulsion, Drug loading

\section{Introduction}

微乳液（microemulsion）是一种由适当比例的表面活性 剂、助表面活性剂、水、油自发形成的各向同性，外观透 明或半透明、热力学稳定的分散体系（Qin et al., 2006）。 1943年微乳液的基本结构由Hoar和Schulman首次发现， 在很长的一段时间内oil in water (O/W) 型微乳液被称为 亲水的油胶团, water in oil (W/O) 型微乳液被称为亲油的 水胶团。直到1959年, Schulman才将上述体系称为“微乳 状液”或 “微乳液”（He et al., 2005）。微乳是一种自发 形成的各向同性、透明、热力学稳定的分散体系（Zhang \& Liu, 2008），同时，微乳液还可以在一定范围内同时增 溶油和水, 且增溶效果好于普通乳状液, O/W 型胶束对油 的增容量为 $5 \%$ 左右, O/W型微乳液对油的增容量可高达 40\%-50\%（Hu, 2007）。微乳作为一种新型的药物载体, 可以提高药物的生物利用度，延长水溶性药物的作用时间

(Zhang \& Liu, 2008)。

阿魏酸广泛存在于自然界的植物之中, 是洋蓟、茄子、玉
米等食物中含量最多的酚酸之一, 也是当归、升麻、川芎 等常用中药的有效成分之一 (Barone et al., 2009; Russell \& Duthie, 2011），其化学名称为4-羟基-甲氧基肉桂酸, 是 桂皮酸的衍生物之一, 具有很强的抗氧化活性, 能够清除 体内多种自由基, 包括过氧化氢、超氧自由基、羟自由基 等 (Zhangetal., 1998)，其对心血管系统、神经系统、肾 脏等都有很强的保护作用, 广泛的应用于心脑血管的治疗

(Liu, 2005)。近年来, 发现其对黑色素形成的关键酶酪 氨酸酶具有很强的抑制作用（Fenoll et al., 2004），另外， 阿魏酸具有防晒能力, 290-330 nm 附近有良好的紫外线吸 收, 可预防和减少此波长紫外线对皮肤的损伤（Liu et al., 2014）。因此，目前阿魏酸及其衍生物被广泛的应用于美 白和防晒产品中, 但由于其溶解性和稳定性较差, 且见光 容易分解（Zhao et al., 2008），使得其在配方应用中存在 一些明显的局限。

本研究根据微乳液的性质, 研究阿魏酸自乳化最佳配方及 制备工艺，旨在提高阿魏酸在水相体系中的溶解度，从而 促使阿魏酸能够更好地应用到美白和防晒化妆品配方中。 


\section{Methods}

\section{Instruments and materials}

1) Test instruments

十万分之一分析天平 (1/100000 electronic balance, XS205 Dual Range; METTLER TOLEDO, Switzerland) , 移液枪（transfer liquid gun, Dragon, China），SZ-100 纳 米粒度/Zeta电位分析仪 (SZ-100 nanoparticle size/Zeta potential analyzer, MS 3000; Malvern, UK），电热恒温鼓风 干燥箱 (DHG Series Heating and Drying Oven, DGG-9070B; Shanghai Senxin Experimental Equipment, China)，恒稳 恒湿箱（Constant Temperature \& Humidity Incubator, HWS Intelligent; Ningbo Jiangnan Instrument Factory, China），雷磁 电导率仪（Rex conductivity meter, DDS-307; Shanghai Jingke Instrument, China) 等仪器应用于本次研究。

\section{2) Materials}

Polyoxyethylene sorbitan monolaurate (Tween 20; BASF, Germany), polyoxyethylene sorbitan monopalmitate (Tween 40; BASF), polyethylene glycol sorbitan monostearate (Tween 60; BASF), polyoxyethylene sorbitan monooleate (Tween 80;BASF), polyoxyethylenesorbitan trioleate (Tween 85; BASF) , sorbitan monolaurate（Span 20; BASF) , PEG 40 (BASF) , Cremophor EL (MACKLIN, China), IPM (CRODA, China), Deionized water (laboratory self preparation), absolute ethanol (99.9\%; Beijing Chemical Plant, China) , Ferulic acid (99\%; MACKLIN) 等试剂应用于本次研究。

\section{Determination of surfactants}

1) Preliminary screening of surface active agents

采用加水滴定法（Wang et al., 2011），将表面活性剂与IPM 以质量比为 $1: 1$, 各精确称量 $2 \mathrm{~g}$ 加入 $50 \mathrm{~mL}$ 烧杯中, 搅拌均匀。 然后往烧杯中每次滴加 $0.5 \mathrm{~mL}$ 的去离子水并搅拌, 记录下体 系由清澈变浑浊时去离子水的添加量, 并计算体系最终去离 子水的百分含量, 选择其中具有较好溶水量的表面活性剂进 行下一步优化，所选表面活性剂如Table 1所示 (Zhou et al., 2015; Shen etal., 2008)。
2) Determination of types and proportions of surfactants by pseudo three phase diagram

助表面活性剂能改变表面活性剂的表面活性及亲水亲油平 衡性, 参与形成胶束, 调整水和油的极性, 水溶性醇可减 小水的极性, 油溶性醇可增加油的极性, 从而影响体系的 相态和相性质的微乳成分。根据文献（Liu et al., 2009）及 配方经验, 初步将上述篎选出来的具有较好溶水量的表面 活性剂 (Tween 40, Tween 60, Tween 80, Cremophor EL, PEG 40）与助表面活性剂乙醇按照质量比为 $3: 1$ 的比例 精确称量并混匀作为混合表面活性剂。按照质量比为 $1: 9$, 2:8，3:7，4:6，5:5，6:4，7:3，8:2，9:1的比例称取混合表 面活性剂和IPM，混合均匀。每次向体系中加入 $1 \mathrm{~mL}$ 的纯 水, 并不断搅拌, 记录临界点时水的质量数, 把相应的点 （各组分百分比）绘制于相图上。

\section{Optimization of surfactant and cosurfactant ratio}

将筛选出的表面活性剂（Tween 40, Tween 60, Tween 80, Cremophor EL, PEG 40) 与乙醇按照质量比为 $0.5: 1$, 1:1，1.5:1，2:1，2.5:1，3:1，3.5:1，4:1的比例精确称取并 混合均匀, 将混合表面活性剂与IPM按照质量比为 $9: 1$ 的比 例混合均匀, 制备含水量为 $90 \%$ 的微乳样品两支。分别置 于 $-20^{\circ} \mathrm{C} 、 45^{\circ} \mathrm{C}$ 环境, $24 \mathrm{~h}$ 后取出恢复至室温观察, 并使 用Zeta电位仪进行粒径的测量。综合比较稳定性与粒径结 果, 选出最佳表面活性剂与助表面活性剂比例。

\section{Determination the ratio of mixed surfactant to oil phase}

将筛选出的表面活性剂与乙醇按照最佳的mass ratio of surfactant and cosurfactant（Km）值，配置成混合表面活 性剂, 将混合表面活性剂与IPM按照质量比为8.5:1, 8:1, $7: 1,6: 1,5: 1$ 的比例混合, 并配置两支含水量为 $90 \%$ 的微乳 样品。一支放入 $45^{\circ} \mathrm{C}$ 环境, 一支放入- $20^{\circ} \mathrm{C}$ 环境, $24 \mathrm{~h}$ 后取 出恢复至室温观察, 并对有必要的样品使用Zeta电位仪进 行粒径的测量, 综合比较稳定性与粒径结果, 找出适合的 混合表面活性剂与油相的比例范围, 进一步细化其比例, 并按照上述步骤观察其稳定性与粒径, 进一步优化混合表 面活性剂与油相的比例。

Table 1. HLB value of 8 surfactants

\begin{tabular}{ccccccccc}
\hline Surfactants & Tween 20 & Tween 40 & Tween 60 & Tween 80 & Tween 85 & Span 20 & Cremophor EL & PEG 40 \\
HLB & 16.9 & 15.6 & 14.9 & 15 & 11 & 8.6 & $12-14$ & $14-16$ \\
\hline
\end{tabular}

HLB, hydrophile-lipophile balance; Tween 20, polyoxyethylene sorbitan monolaurate; Tween 40, polyoxyethylene sorbitan monopalmitate; Tween 60 , polyethylene glycol sorbitan monostearate; Tween 80 , polyoxyethylene sorbitan monooleate; Tween 85 , polyoxyethylene sorbitan trioleate; Span 20, sorbitan monolaurate; Cremophor EL, polyoxyethylene castor oil; PEG 40, polyethylene glycol 40. 


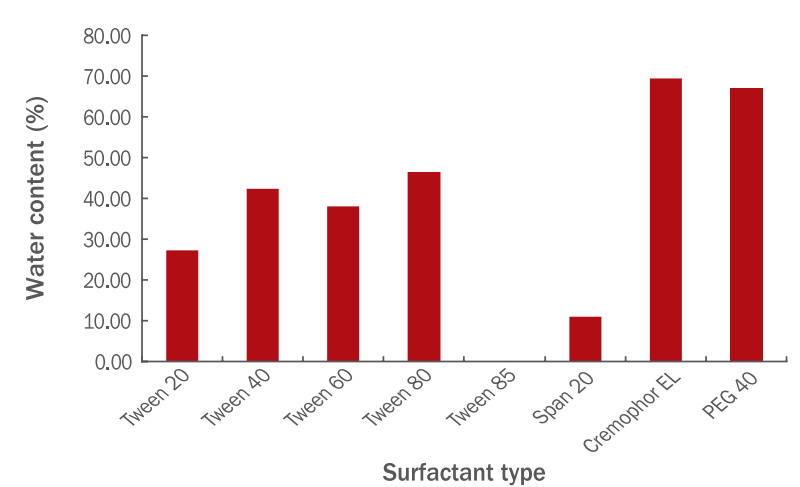

Figure 1. The water content of different surfactants in the mixed system.

It shows the difference in the amount of water in the different surfactant systems. As can be seen from the figure, in the case of the same mass ratio, the water solubility of Tween 40, Tween 60 , Tween 80 , Cremophor EL, PEG 40 is larger, at around $40 \%$ or more. The water solubility of Tween 20 and Span 20 is smaller, What is more, Tween 85 system is turbid after adding $0.5 \mathrm{~mL}$ of pure water. Tween 20, polyoxyethylene sorbitan monolaurate; Tween 40, polyoxyethylene sorbitan monopalmitate; Tween 60 , polyethylene glycol sorbitan monostearate; Tween 80 , polyoxyethylene sorbitan monooleate; Tween 85, polyoxyethylene sorbitan trioleate; Span 20, sorbitan monolaurate; Cremophor EL, polyoxyethylene castor oil; PEG 40, polyethylene glycol 40.

\section{Ferulic acid microemulsion}

1) Preparation of ferulic acid microemulsion 将笁选出的表面活性剂, 助表面活性剂, 以及油相按照最 佳比例制备无水微乳, 将阿魏酸融入, 配置成不同含药浓 度的无水阿魏酸载药微乳。

2) Investigation on the maximum loading and stability of microemulsion system

将不同含药量的阿魏酸微乳配置成含水量分别为 $70 \%$, $80 \%, 90 \%$ 的样品, 密封, 室温环境下放置, 观察。取没 有药物析出现象的为 $O / W$ 型微乳最大载药量。

\section{Identification and quality evaluation of ferulic acid microemulsion}

1) Determination of the structure change of microemulsion by conductivity method

取最大载药量按照最佳配方配置无水载药微乳, 并稀释 成含水量分别为 $10 \%, 20 \%, 30 \% ， 40 \% ， 50 \% ， 60 \%$, $70 \%, 80 \%, 90 \%$ 的样品, 采用雷磁电导仪对其电导率进
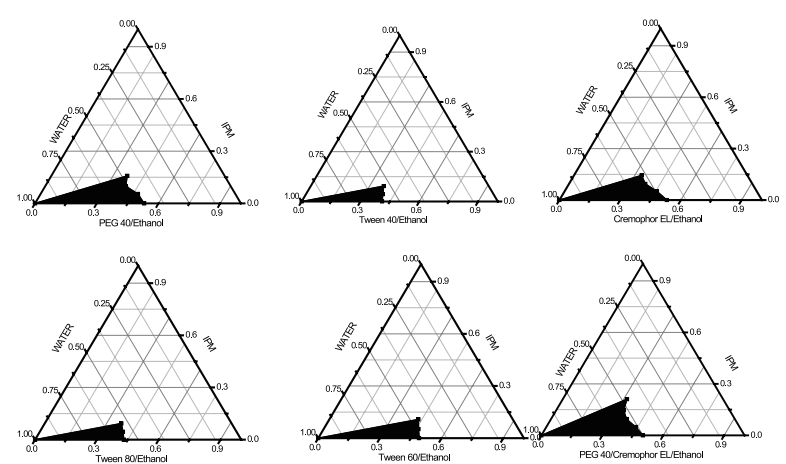

Figure 2. Microemulsion region of surfactant system. As shown in Figure 2, microemulsion area of PEG 40/ethanol and Cremophor EL/ethanol system are larger than other surfactant systems, which is conducive to the preparation of microemulsion. Therefore, Cremophor and PEG 40 were selected to be mixed at the mass ratio of 1:1 in microemulsion area, the formation of mixed microemulsion area was significantly greater than a single surfactant system. IPM, isopropyl myristate; PEG 40, polyethylene glycol 40; Tween 40, polyoxyethylene sorbitan monopalmitate; Cremophor EL, polyoxyethylene castor oil; Tween 80 , polyoxyethylene sorbitan monooleate; Tween 60 , polyethylene glycol sorbitan monostearate.

行测量 (Sun etal., 2015), 记录数据并分析。

2) Changes of micro emulsion particle size in the process of dilution

取最大载药量, 按照最佳配方配置无水载药微乳, 按上述 比例稀释为9组样品, 使用Zeta电位仪对其进行粒径的测

量, 每组样品测量三次, 取平均值。

3) Stability investigation

取最大载药量按照最佳配方配置无水微乳样品, 并稀释成 为含水量分别为 $10 \%, 20 \%, 30 \%, 40 \%, 50 \%, 60 \%$, $70 \%, 80 \%, 90 \%$ 的载药微乳样品, 分为五组, 分别密封放 入室温环境下, 光照环境下, $45^{\circ} \mathrm{C}$ 环境下, $-20^{\circ} \mathrm{C}$ 环境下, $45^{\circ} \mathrm{C}$ 和- $20^{\circ} \mathrm{C}$ 交替环境（各 $12 \mathrm{~h}$ ）。 $24 \mathrm{~h}$ 后, 记录其性质的变 化。

\section{Data processing and analysis}

利用origin 8.0 (OriginLab Corporation, USA) 和Excel 2010软件对实验数据进行处理分析和图像绘制。 


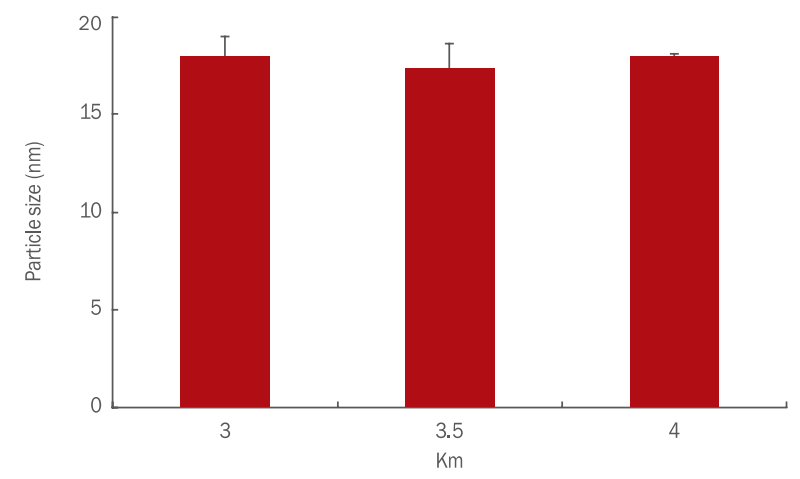

Figure 3. Particle size measurement of microemulsion samples with different $\mathbf{k m}$ in $\mathbf{9 0} \%$ water content.

The particle size of the samples with $\mathrm{Km}$ value of $3,3.5$ and 4 was measured under the condition of $45^{\circ} \mathrm{C}$. When $\mathrm{Km}$ is 3.5 , the average particle size is $15.6 \mathrm{~nm}$ which is less than the other two, the final selection of $\mathrm{Km}$ is 3.5 . $\mathrm{Km}$, mass ratio of surfactant and cosurfactant.

\section{Results \& Discussion}

\section{Screening results of surfactants}

1) Water solubility of different surfactants in oil phase mixing system

因为是制备 $O / W$ 型可稀释微乳, 所以选取 hydrophilelipophile balance (HLB) 值在8以上的表面活性剂, 将乙醇 作为助表面活性剂, IPM作为油相。显示了不同表面活性剂 体系的溶水量的差别。

由Figure 1可以看出, 在相同质量比的情况下, Tween 40, Tween 60, Tween 80, Cremophor EL, PEG 40体系的溶水 量较大, 均在 $40 \%$ 左右或以上。Tween 20 和Span 20 的溶水 量较小, 而Tween 85体系在加入 $0.5 \mathrm{~mL}$ 的纯水后搅拌即浑 浊。而采用加油法, 所有的体系在加入 $0.5 \mathrm{~mL}$ 的IPM后搅拌 即浑浊, 说明加油法并不适合考察油相的溶解量以及微乳液 的制备。综合加水法和加油法的结果, 最终决定使用Tween 40, Tween 60, Tween 80, Cremophor EL, PEG 40进行微 乳液伪三相图的绘制并在其中篮选出最终的表面活性剂。

2) Screening results of phase three phase diagram

如Figure 2所示, PEG 40/乙醇与Cremophor EL/乙醇体系 的微乳区域面积大于其他表面活性剂体系的成乳区域, 说 明PEG 40与Cremophor EL能够形成微乳的比例范围比其他 的表面活性剂大, 有利于制备微乳液。故选用成乳区域较 大的Cremophor EL与PEG 40按照质量比为1:1进行复配, 然 后与乙醇按照3:1的质量比制成混合表面活性剂, 再与IPM 按照9:1的质量比混合配置微乳液, 复配的微乳成乳区域明

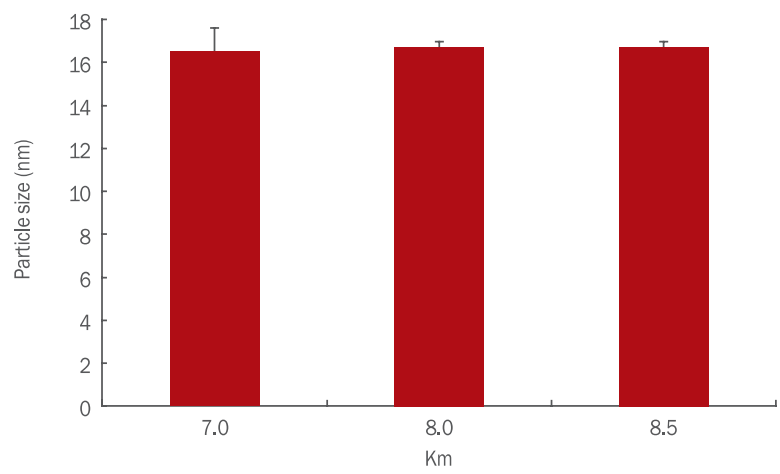

Figure 4. Particle size measurement of $90 \%$ aqueous microemulsion with mixed surfactant to oil phase mass ratio. As shown in Figure 4, the particle size difference between the three groups is not significant. However, considering the time from the frozen condition to the steady state, the mixed surfactant and oil phase mass ratio of 8:1 was finally selected for this study. $\mathrm{Km}$, mass ratio of surfactant and cosurfactant.

显大于单个表面活性剂体系的成乳区域，且Cremophor ELPEG 40复配体系具有良好的稳定性和均匀的粒径分布, 故 最终选定Cremophor EL-PEG 40复配表面活性剂为此次研究 微乳液制备的表面活性剂。

\section{Determination of the ratio of surfactant to cosurfac} tant

处于 $-20^{\circ} \mathrm{C}$ 环境下的微乳样品, 刚开始时所有 $\mathrm{km}$ 值的微乳 样品都变浑浊, 随着静置的时间不断加长, $\mathrm{km}$ 值为 3.5 和 4.0 的微乳样品先恢复至半透明直至透明, $k m$ 为 3.0 的样品 恢复时间要长于 $\mathrm{km}$ 值为 3.5 和 4.0 的样品, 其余仍处于浑浊 状态。通过预实验得知, $45^{\circ} \mathrm{C}$ 环境下的微乳样品粒径更接 近于室温环境下的粒径大小, 几乎没有什么变化, 而 $-20^{\circ} \mathrm{C}$ 环境下的微乳样品恢复后粒径远大于室温环境下的值, 说 明室温环境下的微乳已经发生聚集或时间还未达到所需的 恢复稳定时间。所以对 $45^{\circ} \mathrm{C}$ 环境下 $\mathrm{km}$ 值为 $3,3.5$ 的样品进 行粒径测量, 结果如Figure 3所示, 当 $\mathrm{Km}$ 为 3.5 时其平均粒 径较小, 为 $15.6 \mathrm{~nm}$, 最终选定 $\mathrm{km}$ 为3.5。

\section{Determination of the ratio of mixed surfactant to oil phase}

分别对8.5:1，8:1，7:1，6:1，5:1这五个不同的混合表面活 性剂与油相比例, 含水量为 $90 \%$ 的微乳样品, 进行耐寒耐 热的稳定性观察。发现耐热环境下, 各质量比的样品均无 明显变化，在耐寒环境下，8.5:1，8:1，7:1这三个比例的 样品率先恢复稳定, 其余仍处于浑浊状态, 故选定这三个 


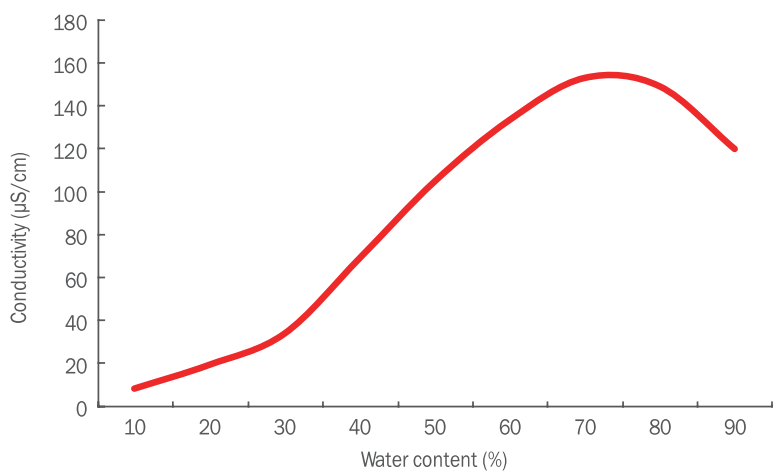

Figure 5. The conductivity of ferulic acid microemulsion during dilution process.

As shown in Figure 5, when the water contained ferulic acid microemulsion in $30 \%$ and below, the conductivity of system increased slowly, which was in type W/O. When the system of water content in 30\%-70\%, the conductivity changes linearly, this stage was roughly in double continuous type. When the water content in the $70 \%$ and above, the conductivity began to decline, and the system has been changed from double continuous into type O/W. W/O, water in oil; O/W, oil in water.

比例进行进一步探究。其结果如Figure 4所示, 虽然质量比 为7:1时, 微乳的平均粒径要略小, 但其恢复至稳定状态的 时间比起质量比为 $8: 1$ 的样品要长得多, 所以综合考虑, 最 终选定混合表面活性剂与油相质量比为 $8: 1$ 为本次研究微乳 配置的配方比例。至此可以确定无阿魏酸微乳的最佳配方 为: CremophorEL:PEG 40:无水乙醇:IPM=3.15:3.15:1.8:1。

\section{The maximum loading and stability of ferulic acid}

通过前期预实验对空白微乳不同水分含量下不同参数的分 析，发现微乳水分含量在 $70 \%$ 左右及以上时微乳体系为 $\mathrm{O} / \mathrm{W}$ 型乳液, 且其稳定性与水分含量有呈反比的趋势。所以, 在本次研究中, 以含水量70\%、80\%、90\%在室温环境下保 持稳定为标准笁选最大载药量。结果如Table 2所示, 在此 环境下，阿魏酸微乳能够保持稳定的最大溶解度为 $5.2 \%$ 。

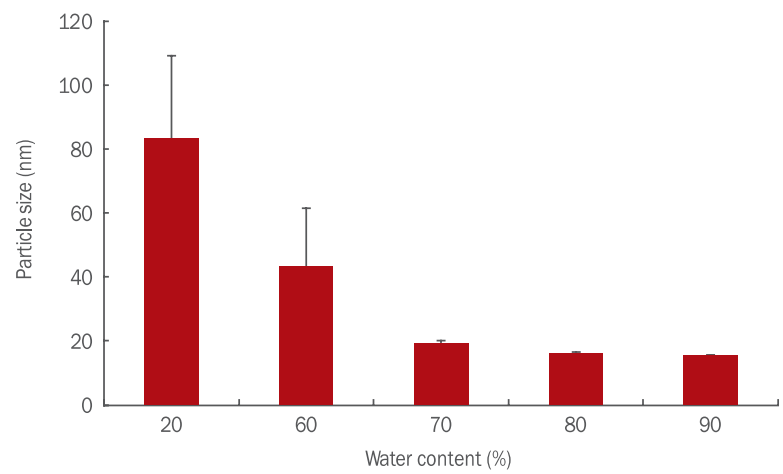

Figure 6. Particle size of ferulic acid microemulsion during dilution process.

As shown in Figure 6, when the water content was less than $10 \%$, there was no measurement results. Because there was no free water in the system existed. When the water content of ferulic acid microemulsion in $20 \%$, the particle size could be measured, indicating that free water has appearred this system, and formed W/O microemulsion. After the water content of ferulic acid microemulsion in $70 \%$, it was found that the particle size of microemulsion was basically no change, indicating that the microemulsion has been made double continuous change for $\mathrm{O} / \mathrm{W}$. Therefore, We could determine the water content of ferulic acid microemulsion changed from double continuous to O/W type at 60\%-70\%. W/O, water in oil; O/W, oil in water.

\section{Quality evaluation of ferulic acid}

1) Determination the microemulsion system type by electrical conductivity method

如Figure 5所示，阿魏酸微乳液的水分含量在30\%及以下 时，体系的电导率增加缓慢，为W/O型; 体系水分含量在 30\%-70\%时, 体系电导率呈线性变化, 这一阶段大致处于 双连续型; 水分含量在 $70 \%$ 及以上时, 体系电导率开始下 降, 此时体系已经由双连续型转变为 $\mathrm{O} / \mathrm{W}$ 型, 符合制备的 剂型要求。

Table 2. Ferulic acid loading

\begin{tabular}{lcccccc}
\hline Different water content in microemulsion & \multicolumn{5}{c}{ Drug loading concentration } \\
\cline { 2 - 7 } $70 \%$ & $5.2 \%$ & $7.6 \%$ & $9.9 \%$ & $12.0 \%$ & $14.1 \%$ & $17.8 \%$ \\
$80 \%$ & $\mathrm{~S}$ & $\mathrm{~S}$ & $\mathrm{NS}$ & $\mathrm{NS}$ & NS & NS \\
$90 \%$ & $\mathrm{~S}$ & $\mathrm{NS}$ & $\mathrm{NS}$ & $\mathrm{NS}$ & NS & NS \\
\hline
\end{tabular}

S, stable; NS, not stable. 
2) Particle size measurement in microemulsion dilution process

如Figure 6所示, 在阿魏酸微乳的稀释过程粒径测量中, 发 现当体系水分含量小于10\%时没有测量结果, 分析此时因 为水分子与表面活性剂的亲水基结合在一起, 体系当中没 有自由水存在, 所以不能测出粒径（Wang et al., 2014）。 水分含量在 $20 \%$ 时, 阿魏酸微乳能够测出粒径, 说明此时 体系中已经出现自由水, 并形成W/O型微乳, 所以可以测 出粒径（Do et al., 2009），阿魏酸微乳液水分含量在 $70 \%$ 以后发现微乳液粒径变化已经不大, 基本没有变化, 说明 此时微乳液已经由双连续型改变为 $\mathrm{O} / \mathrm{W}$ 型, 所以微乳粒径 变化已经不明显（Lin et al., 2014）。水分含量在60\%时 能够测出粒径, 说明此时处于由双连续性向 $\mathrm{O} / \mathrm{W}$ 型转变的 过程中, 因此, 判断阿魏酸微乳的双连续型转变为 $\mathrm{O} / \mathrm{W}$ 型 的水分含量在 $60 \%-70 \%$ 之间, 这个结果与电导率测试的 结果大致相似, 阿魏酸微乳液稀释过程粒径变化, 如Table 3所示, 随着体系水分含量的上升, 微乳的平均粒径逐步 减小, 当体系水分含量为 $90 \%$ 时, 微乳的平均粒径为 15.5 $\mathrm{nm}$ 。在实际的操作过程中，30\%、40\%、50\%含水量的体 系由于其粘度较大, 不易于实际操作, 并且所含气泡较多 会对测量结果有很大影响, 显然不符合我们的制剂要求, 所以没有对这三个水分含量进行测量。

\section{3) Stability test results}

通过在室温环境, 光照环境, $45^{\circ} \mathrm{C}$ 环境, $-20^{\circ} \mathrm{C}$ 环境, $45^{\circ} \mathrm{C}$ 和 $-20^{\circ} \mathrm{C}$ 交替环境（各 $12 \mathrm{~h}$ ），这五种环境下不同含 水量阿魏酸乳液的观察, 以是否保持透明且无沉淀物析出 为指标 (Mahrhauser et al., 2015)，得出结果如Table 4所 示, 发现阿魏酸微乳液的不同含水量的配方在这五类环境 下都有良好的稳定性。

\section{Conclusion}

阿魏酸目前在医药领域的研究较多。其具有抗氧化、抗血 栓功能, 能够降血脂, 防治冠心病以及具有抗突变和防癌 作用（Liang et al., 2009）。其前体可以通过化学合成和植 物提取两条途径获得阿魏酸。1997年日本神户大学医学部 用维生素 $\mathrm{E}$ 与阿魏酸合成维生素 $\mathrm{E}$ 阿魏酸酯, 用于皮肤的美 白护理和祛斑治疗, 发现其对黑色素的形成有很强的抑制 作用, 因此阿魏酸及其衍生物被公认为美容因子 (Chen et al., 2010）。但由于阿魏酸存在在水溶液中溶解度不高,

稳定性较差, 且见光易分解的问题, 应用上受到了很大的 限制。本次课题着重研究了微乳液的配方与阿魏酸微乳 液的稀释过程相变特性, 通过复配不同的表面活性剂和 各相比例的优化, 得出了阿魏酸自微乳的最佳配方为: Cremophor EL:PEG 40:无水乙醇IPM=3.15:3.15:1.8:1，阿魏 酸的最大载药量为 $5.2 \%$, 制备出的阿魏酸微乳具有良好的 载药量和稳定性, 这对于将微乳液技术应用到阿魏酸产品 的生产当中, 具有一定的指导意义。

但本研究还存在一些不完善, 所制备的微乳制剂仍然含有 较高浓度的表面活性剂和助表面活性剂, 并且没有对制得 的阿魏酸微乳液进行安全性和功效性评价, 希望后续的研 究人员能够进一步解决这些问题。

\section{References}

Barone E, Calabrese V, Mancuso C. Ferulic acid and its therapeutic potential as a hormetin for age-related diseases. Biogerontology, 10: 97-108, 2009.

Chen Z, Chang S, Dong Y, He C, Zhu J. Research of modified

Table 3. Particle size of ferulic acid microemulsion in dilution process

(Unit: nm)

\begin{tabular}{lllllll}
\hline Water content & $10 \%$ & $20 \%$ & $60 \%$ & $70 \%$ & $80 \%$ & $90 \%$ \\
Average particle size & $-1)$ & 83.4 & 43.5 & 19.5 & 16.3 & 15.5 \\
\hline${ }^{1)}$ means no result. & & &
\end{tabular}

Table 4. Stability of ferulic acid microemulsion with different water content

\begin{tabular}{|c|c|c|c|c|c|c|c|c|c|}
\hline Water content & $10 \%$ & $20 \%$ & $30 \%$ & $40 \%$ & $50 \%$ & $60 \%$ & $70 \%$ & $80 \%$ & $90 \%$ \\
\hline Room temperature & S & S & S & S & S & $\mathrm{S}$ & S & S & S \\
\hline Illumination & S & S & S & S & S & $\mathrm{S}$ & $\mathrm{S}$ & S & S \\
\hline Cold $\left(-20^{\circ} \mathrm{C}\right)$ & $\mathrm{S}$ & $S$ & $S$ & $S$ & $S$ & $\mathrm{~S}$ & $S$ & $S$ & $S$ \\
\hline Hot $\left(45^{\circ} \mathrm{C}\right)$ & $\mathrm{S}$ & S & S & S & $S$ & $\mathrm{~S}$ & $S$ & $S$ & S \\
\hline Cold and heat exchange & $\mathrm{s}$ & $\mathrm{s}$ & $\mathrm{s}$ & $\mathrm{s}$ & $\mathrm{s}$ & $\mathrm{s}$ & $\mathrm{s}$ & $\mathrm{s}$ & $\mathrm{s}$ \\
\hline
\end{tabular}

S, stable. 
solubility and whitening efficacy of ferulic acid by gluco samine. China Pharmacist, 13: 1715-1718, 2010.

Do LD, Withayyapayanon A, Harwell JH, Sabatini DA. Environmentally friendly vegetable oil microemulsions using extended surfactants and linkers. Journal of Surfactants and Detergents, 12: 91-99, 2009.

Fenoll LG, Peñalver MJ, Rodríguez-López JN, Varón R, GarcíaCánovas F, Tudela J. Tyrosinase kinetics: discrimination between two models to explain the oxidation mechanism of monophenol and diphenolsubstrates. The International Journal of Biochemistry \& Cell Biology, 36: 235-246, 2004.

He YB, Li XY, Ding YP, Qiu ZM. Research advance and application of microemulsion. Science \& Technology in Chemical Industry, 13: 41-48, 2005.

$\mathrm{Hu}$ LL. Research progress and application of microemulsion. Detergent \& Cosmetics, 30:18-21, 2007.

Liang N, Sun SP, Luo YE, Di LZ, Liu B. Research progress of ferulic acid. Heilongjiang Journal of Traditional Chinese Medicine, 3: 39-40, 2009.

Lin L, Yin SS, Liu P, Zhu L, Chen W, Lin J, Zhang J. Preparation of Lianzhang microemulsion. Herald of Medicine, 33: 926931, 2014.

Liu GX, Zhang JY, Wu PX, Li JY, Liu Y, Zhou XZ, Wei XJ, Niu JR, Hu HW. Basic study on different co-surfactant O/W pharmaceutical microemulsions. China Journal of Hospital Pharmacy, 29: 177-180, 2009.

Liu HR. Pharmacological action and clinical application of sodium ferulate. China Pharmaceuticals, 14: 78-79, 2005.

Liu YH, Yang Z, Zhu J. Preparation of ferulic acid esters and their application in cosmetics. Chemical World, 55: 700704, 2014.

Mahrhauser D, Nagelreiter C, Baierl A, Skipiol J, Valenta C. Influence of a multiple emulsion, liposomes and a microemulsion gel on sebum, skin hydration and TEWL. International Journal of Cosmetic Science, 37: 181-186, 2015.
Qin CK, Chai JL, Chen JF. Progress of the research and application of microemulsion. Shanxi Chemical Industry, 26: 21-25, 2006.

Russell W, Duthie G. Plant secondary metabolites and gut health: the case for phenolic acids. Proceedings of the Nutrition Society, 70: 389-396, 2011.

Shen Y, Powell RL, Longo ML. Interfacial and stability study of microbubbles coated with a monostearin/monopalmitinrich food emulsifier and PEG40 stearate. Journal of Colloid and Interface Science, 321: 186-194, 2008.

Sun DM, Chen H, Wang LL, Chen P, Zhou R, Xie Y. Application of specific conductance method in the extraction of effective constituents from traditional Chinese medicines. Chinese Traditional Patent Medicine, 37: 2686-2690, 2015.

Wang WP, Li ZF, Yang JH, Zhang LC. A comparative study on the preparation of wintergreen oil nanoemulsion from different emulsifiers. Lishizhen Medicine and Materia Medica Research, 22: 481-482, 2011.

Wang YH, Fang SB, Gao L, Wang Y, Zhou R. Study of the preparation and physiochemical properties of osthole microemulsion. World Journal of Integrated Traditional and Western Medicine, 9: 257-259, 2014.

Zhang Y, Liu M. Study on the preparation of diammonium glycyrrhizinate microemulsion system. Pharmaceutical Journal of Chinese People's Liberation Army, 24: 148-150, 2008.

Zhang Z, Yao S, Lin W, Wang W, Jin Y, Lin N. Mechanism of reaction of nitrogen dioxide radical with hydroxycinnamic acid derivatives: a pulse radiolysis study. Free Radical Research, 29: 13-16, 1998.

Zhao DP, Yang WY, Chen XF. Research progress of ferulic acid. Lishizhen Medicine and Materia Medica Research, 19: 1839-1841, 2008.

Zhou YW, Liu JF, Jia MJ, Zhao L, Xu BC. Performance and applications of surfactants (X XIV): application of surfactants in medicine. China Surfactant Detergent \& Cosmetics, 45: 670-673, 2015. 


\section{中文摘要}

\section{阿魏酸自微乳制备工艺的研究}

左锦辉, 李强, 董泽原, 孟宏, 李丽, 董银卯”

北京工商大学中国化妆品协同创新中心，北京，中国

目的：研究阿魏酸自微乳最佳配方及制备工艺。方法：采用伪三相图法研究不同表面活性剂对微乳区形成大小的影 响, 并且采用SZ-100纳米粒度分析仪确定表面活性剂、助表面活性剂与油相的最佳比例; 最后利用SZ-100纳米粒 度/Zeta电位分析仪评价微乳质量。结果: 综合伪三相图法和粒度分布仪的结果，确定了不含阿魏酸的自微乳体系 的最佳配方为 polyoxyethylene castor oil (Cremophor EL):polyethylene glycol 40 (PEG 40):无水乙醇:isopropyl myristate (IPM)=3.15:3.15:1.8:1, 微乳平均粒径为 $15.5 \mathrm{~nm}$ (体系水分含量为 $90 \%)$, 阿魏酸的最大载药量为 $5.2 \%$, 其 自微乳配方稳定性良好。结论: 该配方较大的提升了阿魏酸这种难溶性原料在水中的溶解度, 对于将该微乳液应用于 实际生产具有指导意义。

关键词: 美白，阿魏酸，配方工艺，微乳液，载药量 


\section{국문초록}

\section{페룰산의 마이크로 에멀젼 제조공정에 관한 연구}

좌금휘, 이강, 동탁원, 맹홍, 리려, 동은묘*

북경공상대학 중국화장품공동혁신센터, 북경, 중국

목적: 본 연구는 페룰산의 자체 에멀젼을 위한 최적의 포뮬러 및 제조공정을 연구 하기 위한 것이다. 방법: Pseudo three phase diagram방법을 이용하여 각기 다른 계면활성제의 마이크로 에멀젼 영역의 형성 크기에 대한 영향을 연구하고, 또한 SZ-100나노입 자분석기를 이용하여, 계면활성제, 보조계면활성제, 오일의 최적의 비율을 확인하였다. 마지막으로 SZ-100나노입자분석기 및 Zeta 전위 분석기를 이용하여 마이크로 에멀젼의 안정성을 확인하였다. 결과: Pseudo three phase diagram방법과 SZ-100나노입자분석 기를 이용하여 측정한 결과를 종합하여, 최적의 에멀젼 처방비율은 polyoxyethylene castor oil (Cremophor EL):polyethylene glycol 40 (PEG 40):무수에탄올:isopropyl myristate ( $\mathrm{PM})=3.15: 3.15: 1.8: 1$ 이고, 에멀젼의 평균입자크기는 $15.5 \mathrm{~nm}$ 이며, 이때 마이크로 에 멀젼 체계 수분함량은 $90 \%$ 이었다. 페롤산의 최대 약물적재량(maximum drug loading)은 $5.2 \%$ 이며, 에멀젼의 안정성 또한 우수하 다는 것을 확인하였다. 결론: 위와 같은 에멀젼 처방의 연구는 페롤산과 같은 불용성 물질의 수중에서의 용해도를 대폭 증가시킴으 로써, 실제 생산응용 시에 중요한 가치를 가질 것으로 사료된다.

핵심어: 미백, 페룰산, 처방공정, 마이크로 에멀젼, 약물적재량 